\title{
FOR ALL INTENTS AND PURPOSES: \\ WHAT COLLECTIVE INTENTION TELLS US ABOUT CONGRESS AND STATUTORY INTERPRETATION
}

\author{
ABBY WRIGHT $^{\dagger}$ \\ INTRODUCTION
}

While courts in the United States frequently invoke legislative intent and legislative purpose ${ }^{1}$ when interpreting statutes, legal scholars have long questioned whether a multimember body like Congress can have purposes or intentions. Drawing on the philosophical literature on collective intention, this Comment argues that Congress, when enacting statutes, is the type of social organization that has intentions. The same literature on collective intention, however, counsels caution in expanding the list of mental states one should ascribe to Congress.

This Comment begins by defining the contours of legislative intent and legislative purpose and then explore why relying on legislative purpose is appealing to courts. Next, the Comment describes a variety of theories of collective intention and looks in depth at the work of Raimo Tuomela. Third, the Comment analyzes Congress's characteristics as a social entity and applies Tuomela's account of collective intention to Congress, concluding that this account demonstrates that Congress, at least under certain circumstances, can have intentions. The argument runs as follows: to be a member of Congress an individual must agree that when legislation is being written, amended, and voted on certain members of Congress will become "operative" members. Once a bill is passed, all members of Congress

\footnotetext{
${ }^{\dagger}$ J.D. Candidate, University of Pennsylvania Law School, 2006; M.A. linguistics, University of California, Berkeley, 2002; B.A., Purdue University, 2000. I would like to thank Professors Matthew Adler and Theodore Ruger for their insightful comments. In addition, I would like to thank Professor Stephen Burbank, Professor Cary Coglianese, J. Gordon Cooney, and David Castleman for their valuable suggestions. I would also like to thank Morgan Taylor and Lauren Fox for excellent editing. Finally, I want to thank my father for the title of this Comment. All errors are my own.

${ }^{1}$ See infra notes 37-42 and accompanying text for a description of the difference between legislative intent and legislative purpose as used in this Comment.
} 
have an obligation to accept, at least weakly, that text as the group's intention; the minority members of Congress have agreed to "give up their will with respect to group-binding group-goal formation [in this instance the text of the statute that was passed] and transfer that right to the operative members." ${ }^{2}$

Finally, this Comment argues that while legislative purpose is an appealing tool for determining the scope of statutes, analyses using "legislative purpose" are misguided because the uniqueness and complexity of Congress as a social group limits the application of theories of collective intention. ${ }^{3}$ Members of Congress cannot be said to have agreed in advance to accept the larger purposes and hopes that various members of Congress might possess when enacting legislation. Therefore, when a judge purports to base a decision on legislative purpose, if the decision is to be justified, it must be supported by considerations extrinsic to the legislative process and any theory of collective intention.

\section{LEGISLATIVE INTENT AND PURPOSE IN STATUTORY INTERPRETATION}

\section{A. Hibbs and Allapattah}

In the 2003 Term, a divided Supreme Court decided Hibbs $v$. Winn, ${ }^{4}$ bringing the hotly contested concepts of legislative intent and legislative purpose to the fore. The respondents in Hibbs challenged an Arizona law that provided a tax credit for contributions to organizations awarding scholarships to children attending private, and possibly religious, schools. ${ }^{5}$ The issue before the Court was whether the Tax Injunction Act (TIA) ${ }^{6}$ prohibited a suit to enjoin a state tax credit of this kind. ${ }^{7}$ The TIA states that "district courts shall not enjoin, suspend or restrain the assessment, levy, or collection of any tax under State law where a plain, speedy and efficient remedy may be had in

${ }^{2}$ Raimo TuOmela, The Importance of Us: A Philosophical StUdy OF Basic SOCIAL NOTIONS 279 (1995).

${ }^{3}$ See infra note 177 and accompanying text (describing Congress as a group with a "complex and detailed division and specialization of labor"); infra Part IV.F (arguing that Congress has collective intention only to the point that "nonoperative members have some obligation to at least weakly accept the operative members' jointly accepted intention").

${ }^{4} 542$ U.S. 88 (2004)

${ }^{5} \mathrm{Id}$. at $94-95$.

${ }^{6} 28$ U.S.C. $\$ 1341$ (2000).

${ }^{7}$ Hibbs, 542 U.S. at 93. 
the courts of such State." ${ }^{8}$ The majority ultimately determined that the TIA did not bar such a suit because neither the word assessment nor the statute's underlying purpose prohibited a suit where the repeal of the tax would increase the state's finances.

The Court began its analysis with a somewhat strained study of the language of the statute and determined that the term assessment has a "collection-propelling function." Thus, according to the majority, a lessening of state tax burdens would not fall under the TIA's terms because it would not be an assessment, levy, or collection of tax. Crucially, however, the Court went on to analyze the purpose of the TIA, concluding, in agreement with Judge Easterbrook, ${ }^{10}$ that $§ 1341$ 's purpose was to "restrain state taxpayers from instituting federal actions to contest their liability for state taxes, but not to stop third parties from pursuing constitutional challenges to tax benefits in a federal forum."11

Justice Kennedy, in his dissent, responded with a vigorous disagreement over the meaning of assessment as used in the TIA. He stated that "an assessment... must at the least encompass the recording of a taxpayer's ultimate tax liability." ${ }^{12}$ Thus, enjoining the Arizona tax credit in question would affect the assessment of a state tax because it would alter the amount of tax recorded for the taxpayer. Justice Kennedy rejected the idea that the TIA's purpose could have an independent, interpretive life of its own, stating that "the scope and purpose of the Act should be understood from its terms alone."13 Justice Kennedy further noted that an interpretation of the TIA as prohibiting any interference with state tax schemes "accords with the direct, broad, and unqualified language of the statute ... '[W]hen terms are unambiguous we may not speculate on probabilities of intention." "14 For Justice Kennedy, the words of the statute are what should determine its application; the broader legislative purpose of a statute should have no separate role in interpretation.

828 U.S.C. $\$ 1341$.

${ }^{9}$ Hibbs, 542 U.S. at 102.

${ }^{10}$ See Dunn v. Carey, 808 F.2d 555, 558 (7th Cir. 1986) ("The legislative history ... shows that $\S 1341$ is designed to ensure that federal courts do not interfere with states' collection of taxes, so long as the taxpayers have an opportunity to present to a court federal defenses to the imposition and collection of the taxes.").

${ }^{11}$ Hibbs, 542 U.S. at 108.

${ }^{12} I d$. at 115 (Kennedy, J., dissenting).

${ }^{13} \mathrm{Id}$. at 114.

${ }^{14} I d$. at 126 (quoting Merchs'. Ins. Co. v. Ritchie, 72 U.S. 541, 545 (1866)). 
While Justice Kennedy was in the minority in Hibbs, he wrote the majority opinion for a similar statutory interpretation case, Exxon Mobil Corp. v. Allapattah Services, Inc., ${ }^{15}$ decided quite recently. The Allapattah Court held that 28 U.S.C. $\$ 1367$ "authorized supplemental jurisdiction over all claims by diverse parties arising out of the same Article III case or controversy." ${ }^{\text {"16 }}$ Justice Kennedy reaffirmed his belief that " $[\mathrm{e}] \mathrm{xtrinsic}$ materials have a role in statutory interpretation only to the extent they shed a reliable light on the enacting Legislature's understanding of otherwise ambiguous terms." ${ }^{17}$ The debate between majority and dissent, however, centered on the proper reading of the statute and not the role of legislative history and legislative purpose. ${ }^{18}$ Only Justice Stevens' dissent invoked the statute's legislative history; ${ }^{19}$ the main dissenting opinion did "not rely on the measure's legislative history." ${ }^{20}$ Thus, while Allapattah demonstrates the continuing debate over techniques of statutory interpretation, the actual issue was not, as in $H i b b s$, the validity of legislative purpose.

For the respondents in Hibbs and Allapattah, the 5-4 decisions mean that one Justice's theory of statutory interpretation determined the success of their claim. These cases illustrate how divisive the debates over the use of legislative intent and legislative purpose have become. While, as in Hibbs and Allapattah, the Justices opposed to the use of legislative purpose can be identified as the more conservative members of the Court, conservative positions are not necessarily aligned with a more restrictive understanding of statutory interpretation. $^{21}$ Furthermore, Hibbs is but one example of a long line of cases

15125 S. Ct. 2611 (2005).

${ }^{16} I d$. at 2625.

${ }^{17} I d$. at 2626.

18 See id. at 2632 (Ginsburg, J., dissenting) (advocating a "narrower construction" of $\S 1367$ than that employed by the majority).

${ }^{19} I d$. at 2628 (Stevens, J., dissenting).

${ }^{20} I d$. at 2641 n.14 (Ginsburg, J., dissenting).

${ }^{21}$ Compare Joint Brief of Industry Intervenor-Respondents at 2, Massachusetts v. EPA, 2005 U.S. App. LEXIS 14311 (D.C. Cir. July 15, 2005) (No. 03-1361) (opposing broader regulation of greenhouse gas emissions and stating that the court should use the Clean Air Act's "text, its overall structure, and legislative history" in interpreting the statute), with Final Brief for the Petitioners in Consolidated Cases at 13, Massachusetts v. EPA, 2005 U.S. App. LEXIS 14311 (D.C. Cir. July 15, 2005) (No. 03-1361) (supporting regulation of greenhouse gas emissions and urging a reading of the Clean Air Act's "plain language" when determining the EPA's authority to regulate greenhouse gas emission standards). 
where a majority has looked to legislative purpose ${ }^{22}$ to interpret a statute. $^{23}$ The question remains, however, whether this use of legislative purpose (and even legislative intent) in statutory interpretation is justifiable. Furthermore, the inquiry into whether such tools are justified presupposes that legislatures have intents or purposes.

This Comment seeks to evaluate this claim: that the nature of Congress as a social group is such that Congress has intents and purposes. Without a positive answer to this question, courts arguing from legislative intent or legislative purpose would only be masking other interpretive techniques (be they policy concerns, personal opinion, etc.) when they claim to be relying on a legislature's state of mind. This Comment argues, based on theories of collective intention found in the philosophical literature, that a judge or court can sensibly speak of legislative intent in the narrow sense defined in Part II.A, but not of legislative purpose. Being able to sensibly speak of legislative intent does not mean that a judge or court is necessarily justified in relying on legislative intent in statutory interpretation ${ }^{24}$ or that legislative intent is necessarily determinable in every case; this Comment seeks only to answer the more limited question of whether Congress is the type of social group that makes "legislative intent" possible.

\section{B. The Debate over Legislative Intent}

The use of legislative intent in statutory interpretation has long been controversial. It has been attacked as impossible and unknow-

\footnotetext{
${ }^{22}$ Although the Court in these cases sometimes uses the words "intend" or "intent," the reasoning fits this Comment's definition of legislative purpose. See infra note 41.

${ }^{23}$ See, e.g., Nat'l Private Truck Council, Inc. v. Okla. Tax Comm'n, 515 U.S. 582, 590 (1995) ("In concluding that Congress did not authorize damages actions in state tax cases brought in federal court, we found no evidence that Congress intended $\S$ 1983 to overturn the principle of federalism invoked in Dows and subsequently followed by the courts."); Will v. Mich. Dep't of State Police, 491 U.S. 58, $65-66$ (1989) ("Our conclusion that a State is not a 'person' within the meaning of $\S 1983$ is reinforced by Congress' purpose in enacting the statute. . . Congress, in passing $\S 1983$, had no intention to disturb the States' Eleventh Amendment immunity and to so alter the federal-state balance....”); City of Riverside v. Rivera, 477 U.S. 561, 578 (1986) ("A rule of proportionality would make it difficult ... for individuals with meritorious civil rights claims but relatively small potential damages to obtain redress from the courts. This is totally inconsistent with Congress' purpose in enacting $\S 1988 . ")$; United Steelworkers v. Weber, 443 U.S. 193, 201-02 (1979) (rejecting an interpretation of Title VII that would prohibit all affirmative action programs as contrary to the purpose of the statute).

${ }^{24}$ For example, one could still argue that legislative intent is irrelevant or undemocratic.
} 
able $^{25}$ and, even if possible, irrelevant ${ }^{26}$ to the task of statutory interpretation. Much recent literature, however, has defended the use of legislative intent in statutory interpretation. Some literature has viewed questions of legislative intent in light of the nature of language itself $^{27}$ or the nature of our concepts about the actions of multimember organizations. ${ }^{28}$

${ }^{25}$ See, e.g., Frank H. Easterbrook, Text, History, and Structure in Statutory Interpretation, 17 HARV. J.L. \& PUB. POL'Y 61, 68 (1994) ("Intent is elusive for a natural person, fictive for a collective body."); Max Radin, Statutory Interpretation, 43 HARV. L. REV. 863 (1930), reprinted in LAW AND LANGUAGE 189, 196 (Frederick Shauer ed., 1993) ("A legislature certainly has no intention whatever in connection with words which some two or three men drafted, which a considerable number rejected, and in regard to which many of the approving majority might have had, and often demonstrably did have, different ideas and beliefs."); Kenneth A. Shepsle, Congress Is a "They," Not an "It": Legislative Intent as Oxymoron, 12 INT'L REV. L. \& ECON. 239, 254 (1992) ("Individuals have intentions and purpose and motives; collections of individuals do not. To pretend otherwise is fanciful."); see also William N. EsKRIDGE, JR., DyNAMIC STATUTORY INTERPRETATION 16-21 (1994) (claiming not that legislative intent is never discoverable or always irrelevant, but rather arguing that actual congressional intent is almost always unknowable and conventional intent (i.e., what a given subgroup states is the intent of the legislature) is equally unhelpful because of the presence of vote counting, strategic behavior, and aggregation).

${ }^{26}$ See, e.g., Radin, supra note 25, at 197-98 (arguing that even if the intention of the legislature were determinable, it would be irrelevant for purposes of statutory interpretation because it does not bind current interpreters, given that the legislature cannot be said to have performed the interpretation in advance).

${ }^{27}$ See, e.g., Larry Alexander \& Saikrishna Prakash, "Is That English You're Speaking?": Why Intention Free Interpretation Is an Impossibility, 41 SAN DIEGO L. REV. 967, 982 (2004) (arguing that "recourse to intentions" is necessarily required for any interpretation of a text and, indeed, to identify a series of marks on a page as a text); Lawrence M. Solan, Private Language, Public Laws: The Central Role of Legislative Intent in Statutory Interpretation, 93 GEO. L.J. 427, 434 (2005) ("[T] he distinction between the language of a statute and the intent of the legislature is largely a false one.”); Peter M. Tiersma, A Message in a Bottle: Text, Autonomy, and Statutory Interpretation, 76 TUL. L. REV. 431, 440 (2001) ("Virtually any linguist would agree that the goal of interpretation is to determine what the ... author intends to communicate to his audience.").

${ }_{28}$ See, e.g., M.B.W. Sinclair, Legislative Intent: Fact or Fabrication?, 41 N.Y.L. SCH. L. REV. 1329, 1351-58 (1997) (reviewing William N. ESKRIDGE, JR., DYNAMIC STATUTORY INTERPRETATION (1994)) (citing John Searle, Margaret Gilbert, and Michael Bratman for the proposition that legislative intent need not be the sum of individual intents in order to attack Eskridge's dismissal of legislative intent); Solan, supra note 27, at 438-40 (defending legislative intent with reference to the work of Margaret Gilbert and Michael Bratman); Charles Tiefer, The Reconceptualization of Legislative History in the Supreme Court, 2000 WIS. L. REV. 205, 259-64 (applying John Searle's philosophy of collective intention to account for the institutional intention of Congress); $c f$. Elizabeth $\mathrm{S}$. Anderson \& Richard H. Pildes, Expressive Theories of Law: A General Restatement, $148 \mathrm{U}$. PA. L. REv. 1503, 1514-27 (2000) (using Margaret Gilbert's work on plural subjects to argue that the democratic state is a collective agent); Kent Greenawalt, Constitutional and Statutory Interpretation, in THE OXFORD HANDBOOK OF JURISPRUDENCE AND Philosophy OF LAW 268, 283-84 (Jules Coleman \& Scott Shapiro eds., 2002) (claim- 
Although some of the literature supporting the use of legislative intent has styled itself as a response to textualism, a more moderate version of textualism need not exclude the use of legislative intent in statutory interpretation. ${ }^{29}$ Textualists take the position that "statutory text is the most determinate basis for statutory interpretation." ${ }^{30}$ Even though the text may be the central focus of the interpretive task for a textualist, textualists arguably still recognize the role of legislative intent, but simply seek to limit evidence of intent almost entirely to the text itself. ${ }^{31}$ Thus, the trend seems to be towards an acceptance of the necessity of legislative intent, even if in a much reduced form. ${ }^{32}$

Despite the recent warming to legislative intent, old doubts remain about the possibility of discerning intent when the intent in question must emanate from a group of persons, especially a group with as varied an array of aspirations, agendas, and motivations as Congress. ${ }^{33}$ These concerns are even more amplified with respect to

ing that groups can have intents under certain conditions, but arguing that the real question is "whether judges should take into account the attitudes of legislators").

${ }^{29}$ For a description of a very extreme form of textualism, see Alexander \& Prakash, supra note 27, at 968, calling the "insistence that intentions play no role in the production of meaning ... 'intention free textualism." Justice Scalia, in a recent article, appears to approach this extreme. See Antonin Scalia, Law E Language, FIRST Things, Nov. 2005, at 37, 43 (reviewing STEVEn D. SMith, LAW's QuANDARY (2004)) ("Alice [in Wonderland] and I believe that words, like other conventional symbols, do convey meaning, an objective meaning, regardless of what their author 'intends' them to mean ....")

${ }^{30}$ ESKRIDGE, supra note 25 , at 38 .

31 See Peter M. Tiersma, Legal Language 127 (1999) ("To be more exact, textualism claims that it does try to discover the intent of the legislature, but limits this inquiry to the text of the statute itself."). Tiersma elsewhere states that "[e]veryone should be a textualist sometimes," arguing that limiting the interpretive task to the text may be appropriate for highly 'autonomous' legal texts. Tiersma, supra note 27, at 482.

${ }^{32}$ Even "strict" textualists and those who apparently reject legislative intent as undemocratic or ontologically impossible rely on at least a restricted view of intention. For example, Justice Holmes wrote that "[w]e do not inquire what the legislature meant; we ask only what the statute means," but earlier in the essay he had expressed that "we inquire what he meant in order to find out what he has said." Oliver Wendell Holmes, The Theory of Legal Interpretation, 12 HARV. L. REV. 417 (1899), reprinted in LAW AND LANGUAGE, supra note 25, at 185, 186-87. While Judge Easterbrook has been, at times, skeptical of the existence of congressional intent, he seems to accept a kind of legislative intent which "informs a reading of a text, tells us its meaning." Easterbrook, supra note 25, at 64; see also Solan, supra note 27, at 453-58 (discussing examples from judicial opinions in which textualists resorted to using terms related to the intent of the legislature).

${ }^{33}$ See ESKRIDGE, supra note 25, at 16 ("That most members of Congress voted for a bill tells us little about what most members of Congress actually thought . . . Problems with identifying the actual intent of individual legislators become overwhelming when 
using legislative purpose to determine the meaning of a statute because legislative purpose requires inferences even further removed from the text of the statute. Thus, this Comment examines both legislative intent and legislative purpose in light of Congress's nature as a social group.

\section{The Argument}

As described above, serious doubts about the existence of legislative intent remain, despite a close to universal reliance on authorial intent to at least some degree in the interpretation of statutes. ${ }^{34}$ Furthermore, while the Supreme Court frequently resorts to discussions of legislative purpose in interpreting statutes, many scholars do not believe legislative purpose is a justifiable technique of statutory interpretation. $^{35}$ Thus, the problem is the following: Does the nature of Congress as a social group combined with the properties of statutory text allow us to make inferences about Congress's intent? If so, does the same hold true for inferences about Congress's purpose?

I argue that there is a plausible account of collective intention that can be fruitfully applied to Congress. Although several recent legal articles have drawn on philosophical theories of collective action and intention, ${ }^{36}$ these articles have not examined the breadth of literature available. Part II of this Comment defines the contours of legislative intent and purpose and explores why reliance on legislative purpose is so appealing. Part III lays out the scope of theories on collective action and intention. Part IV argues that an account of collective intention that recognizes the complex structure of an organization in which certain members are authorized to set group goals suitably tied to the purpose of the group can plausibly support inferences regarding Congress's intent. I further argue, however, that Congress cannot fulfill the requirements of a supraindividualist account of collective intention or an account that requires every participant to espouse the requisite intention. The last section of Part IV further argues that while theories of collective intention demonstrate that ascertaining legislative intent is possible (at least in theory), the same cannot be

\footnotetext{
these hard-to-figure individual intentions must be aggregated for each legislative chamber...."); see also supra note 25 and accompanying text (discussing the difficulty of knowing Congress's intent).

${ }^{34}$ See supra notes 28-30 and accompanying text.

35 See infra note 46 and accompanying text.

${ }^{36}$ See supra note 28 and accompanying text.
} 
said of legislative purpose. Thus, when a judge purports to base a decision on legislative purpose, this decision must, in fact, be supported by considerations extrinsic to the legislative process and any inferences that might be drawn therefrom.

\section{LEgislative PURPOSE}

\section{A. Legislative Intent and Legislative Purpose}

Many scholars discuss two kinds of intent, distinguishing between either intended meaning and intended goals ${ }^{37}$ or specific intent and purpose. ${ }^{38}$ Other scholars and judges fail to delineate the contours of legislative intent at all. While the distinction between intent and purpose is by no means crystal clear, I take legislative intent to mean the narrow intent an author has when writing a text: what message she hopes to communicate via the words chosen. This view of intention makes use of what cognitive linguists have recognized as the conduit metaphor. ${ }^{39}$ The source domain, which is the primary field of realworld experience from which the metaphor is drawn, is the world of physical objects that can be transferred between individuals; the target domain, the domain explained by the metaphor, is the world of mental operations. ${ }^{40}$ In the conduit metaphor, words are the vehicles that transfer ideas between individuals. The speaker places ideas into the words, while the hearer extracts the ideas from the words received. Thus, a legislator's intent, in my sense, is the idea she sought to trans-

\footnotetext{
${ }^{37}$ See, e.g., Alexander \& Prakash, supra note 27, app. at 994-95 (distinguishing "what to say to convey what one means" from "what that meaning would accomplish").

${ }^{38}$ See, e.g., ESKRIDGE, supra note 25, at 26 ("[A]n inquiry into legislative purpose is set at a higher level of generality than an inquiry into specific intentions...."); Greenawalt, supra note 28, at 288 ("A crucial question about any approach to the meaning of a statute is how much weight to give to purposes, as contrasted with the language of particular provisions and indications of specific intent.").

${ }_{39}$ See generally Michael J. Reddy, The Conduit Metaphor: A Case of Frame Conflict in Our Language about Language, in METAPHOR AND THOUGHT 164 (Andrew Ortoney ed., $2 d$ ed. 1993) (analyzing the metaphor and providing an appendix with 141 examples of sentences using the metaphor); see also STEVEN L. WINTER, A CLEARING IN THE FOREST: LAW, LIFE AND MIND 52-53 (2001) (describing and mapping the metaphorical structure).

${ }^{40}$ See WINTER, supra note 39, at 52-53 ("In this conceptual mapping, a concept or idea is understood as an object subject to inspection, physical manipulation, and transportation ....”).
} 
fer using the words she chose to speak. In some ways, then, my definition of legislative intent is rather limited. ${ }^{41}$

Legislative purpose, on the other hand, I take to mean what a legislator imagines or hopes will change about the world by means of enacting the legislation. ${ }^{42}$ This statement is not free from complication. Because the act of passing legislation changes something about the world and is a performative utterance, ${ }^{43}$ I mean legislative purpose to be something more than what Congress intends the direct effect of the legislation to be. For example, 42 U.S.C. $§ 1988$ (b) awards fees to attorneys in civil rights cases. Legislative intent, what Congress sought to communicate, would be the direct result that attorneys be awarded fees if representing a prevailing party. In contrast, legislative purpose might be to increase the number of attorneys willing to take civil rights cases. Thus, legislative purpose is a secondary effect the statute seeks to bring about.

Both legislative intent and legislative purpose in my sense are distinguishable from what Judge Easterbrook has called "raw intent"that is, intent without any law, meaning that a "law" could be enforced if it comported with a legislative purpose that had no instantiation in an actual statute. ${ }^{44}$ This is, however, no longer a serious contender as an interpretive theory. ${ }^{45}$

Like the debate over legislative intent, scholars disagree over whether legislative purpose may be taken into account during statutory interpretation. ${ }^{46}$ Many scholars argue that legislative purpose

${ }^{41}$ What evidence one may use to determine what meaning the legislators hoped the words would carry is a separate question, and one this Comment does not try to answer.

${ }^{42}$ This is similar to a distinction made in Sinclair, supra note 28, at 1356.

43 See infra note 182 and accompanying text (arguing that the structure of a statute, combined with the words chosen by its authors, is a speech act that has a "performative" impact on its subjects).

${ }^{44}$ Easterbrook, supra note 25, at 64-65.

${ }^{45}$ The Supreme Court stated unanimously in P.R. Department of Consumer Affairs $v$. Isla Petroleum Corp., 485 U.S. 495, 501 (1988), that "unenacted approvals, beliefs, and desires are not laws," reversing the court of appeals. Thus, the lower court's approval of such an approach seems to be an outlier.

${ }^{46}$ Compare Henry M. Hart \& Albert M. Sacks, The Legal Process: Basic PROBLEMS IN THE MAKING AND APPLICATION OF LAW 1125 (1994) ("The first task in the interpretation of any statute (or any provision of a statute) is to determine what purpose ought to be attributed to it. The principal problem in the development of a workable technique of interpretation is the formulation of ... acceptable criteria for the attribution of purpose."), with Alexander \& Prakash, supra note 27, app. at 994-95 (arguing in favor of intentionalists who "only advocate[] honoring the intent of the lawmaker at the spe- 
should not be taken into account because it is too far removed from the actual words enacted by the legislature, ${ }^{47}$ even though the Supreme Court still embraces legislative purpose ${ }^{48}$ quite frequently. ${ }^{49}$

\section{B. Why Legislative Purpose Is Appealing}

While it is not my goal to describe statutory construction itself in any detail in this Comment, I would like to briefly describe why and when the use of legislative purpose is particularly attractive. This supports the argument that it is crucial to determine whether a determination of legislative purpose, in addition to legislative intent, is possible.

First, it is important to understand the linguistic concepts involved in creating and interpreting legislation. Statutory construction in hard cases is an act of conceptual categorization. Linguists such as Charles Fillmore and George Lakoff have spent decades analyzing the conceptual structures that explain and motivate our use and understanding of language. Professor Fillmore's analysis has taken the form of frame semantics:

Frame semantics offers a particular way of looking at word meanings .... [T] he term 'frame' [means] ... any system of concepts related in such a way that to understand any one of them you have to understand the whole structure in which it fits ....

... [W] ords represent categorizations of experience, and each of these categories is underlain by a motivating situation occurring against a background of knowledge and experience. ${ }^{50}$

cific level of generality that the lawmaker meant to convey, even if at that level it thwarts the lawmaker's more general intentions").

${ }^{47}$ Furthermore, the use of legislative purpose might be argued to be undemocratic since laws are passed by elected representatives, while purposes are most often not part of the codified law. Thus, some have argued that if, but only if, laws were handed down by a dictator, her purpose in passing such laws would be relevant. See Holmes, supra note 32, at 187 ("If supreme power resided in the person of a despot who would cut off your hand or your head if you went wrong, probably one would take every available means to find out what was wanted.").

${ }^{48}$ Here I mean legislative purpose as I have described; as described supra note 22, the Court sometimes labels this Congress's intention. These intentions are purposes in my sense: they are related to the goals and objectives a statute can be said to support.

${ }^{49}$ See supra note 23 (pointing to decisions in which the Supreme Court relied on congressional purpose).

${ }^{50}$ Charles J. Fillmore, Frame Semantics, in Linguistics In THE MORNING CALM 111, 111-12 (Linguistic Soc'y of Korea ed., 1982). For the most recent work on frame semantics and a bibliography of works using the theory, see Framenet, http://www.icsi.berkeley.edu/ framenet (last visited Jan. 18, 2006). 
One example of work in cognitive linguistics relevant to statutory interpretation is Professor Fillmore's analysis of the term orphan. ${ }^{51}$ Professor Fillmore argues that orphan must be analyzed against the background of a culture in which children depend on their parents for support. Thus, the category of orphan "does not have 'built into it' any specification of the age after which it is no longer relevant to speak of somebody as an orphan"; rather, this is understood through the background information, or frame, of relationships between parents and children in a particular culture. ${ }^{52}$ In his analysis, Professor Fillmore points to the old joke where a child on trial for murdering his parents asks the court to be lenient because he is now an orphan. Given the frame in which orphan is situated, a person cannot "orphan" herself. ${ }^{53}$ As Professor Fillmore's orphan example illustrates:

The descriptive framework ... is one in which words ... are seen as indexing semantic or cognitive categories which are themselves recognized as participating in larger conceptual structures of some sort, all of this made intelligible by knowing something about the kinds of settings or contexts in which a community found a need to make such categories available to its participants .... ${ }^{54}$

Professor Lakoff's analysis has described the meaning of concepts in terms of radial categories. ${ }^{55}$ Radial categories are highly structured conceptual groupings with prototypical, salient, or ideal members forming the center of the category and more peripheral members being judged as members of the category to a lesser degree. ${ }^{56}$ Radial categories have a complex internal structure with connections of different types existing between members of the category. ${ }^{57}$

Reflecting on Lakoff's and Fillmore's linguistic analyses, two situations emerge where statutory construction seems to require legislative (or rule-making) purpose. The first is when a judge must decide what

${ }^{51}$ See Fillmore, supra note 50, at 118 (using the orphan example to demonstrate "the complexity of fit between uses of [a] word and real world situations to be attributed to the details of the prototype background frame rather than to the details of the word's meaning"); see also WINTER, supra note 39, at 85-87 (discussing Fillmore's analysis of bachelor).

${ }^{52}$ Fillmore, supra note 50, at 118.

${ }^{53} I d$.

${ }^{54} I d$. at 119.

${ }^{55}$ George Lakoff, Women, Fire, and Dangerous Things: What Categories REvEAL ABOUT THE MIND 68-135 (1987).

${ }^{56} I d$. at 65, 91.

${ }^{57}$ See WINTER, supra note 39, at 89-92 (drawing on LAKOFF, supra note 55), for an interesting discussion of the complexities of the category mother. 
the boundaries of a particular category are, in a context in which the legislature or rule-making body clearly had no intent with respect to a new object or event.

For example, in Mead Corp. v. United States ${ }^{58}$ the court had to determine whether a day planner fit within the category described by Section 4820.10.20 of the Harmonized Tariff Schedules of the United States: "[d]iaries, notebooks and address books, bound; memorandum pads, letter pads and similar articles. ${ }^{, 59}$ This was not, properly speaking, a debate that could be won by determining the "proper" meaning of day planner. Rather it was a debate over the boundaries of the concepts diary and bound. In this case it would have been extremely useful to know the purpose for which the category had been created: Why did the agency exempt some materials from tariff?

This question mirrors Professor Fillmore's statement of what is necessary to understand the term orphan. Categories take on the structure they do precisely because they relate to some goal or purpose of the language community: why "a community found a need to make such categories available to its participants." ${ }^{60}$

In terms of radial categories, the agency's purpose would tell us whether day planners should be within the radial category whose central or prototypical member is diary. The purpose the agency had in enacting the tariff could alert a court to the inner structure of the category and whether that structure extends the categories to include day planners. The agency's purpose would in this way tell a court why the members of the category have been placed in the category-that is, what internal structure holds them together? Thus, it is only natural to turn to the purpose of the legislation (or, as in this case, the rule-making agency) as a guide to determining whether a particular object or event falls within a given category.

The second situation where Lakoff's and Fillmore's work provides insight is one in which two possible categorizations of a concept conflict. Such was the case in determining the meaning of enterprise in $\mathrm{Na}$ tional Organization for Women v. Scheidler; the Court had to determine if an antiabortion group was an enterprise as defined by the Racketeer Influenced and Corrupt Organization Act (RICO) in order to determine whether the group could be liable for its activities. ${ }^{61}$ The Court

${ }^{58} 185$ F.3d 1304 (Fed. Cir. 1999), rev'd in part, United States v. Mead Corp., 533 U.S. 218 (2001).

${ }^{59}$ Id. at 1306-10 (emphasis added).

${ }^{60}$ Fillmore, supra note 50, at 119.

${ }^{61} 510$ U.S. 249, 250, 256-61 (1994). 
did not require an enterprise to have an economic purpose and, thus, held that Pro-Life Action Network (PLAN) could, in theory, be an enterprise for purposes of RICO. ${ }^{62}$

Following the case, three linguists and a law professor devised an experiment to determine whether the Court's interpretation matched that of English speakers. ${ }^{63}$ This experiment revealed two groups of speakers: those who required an enterprise to have a profit-seeking or economic goal and those who only required some sort of organizational goal. ${ }^{64}$ These two conceptualizations of enterprise correspond to the debate in the courts; understanding more about the purposes of those who enacted RICO would shed light on which categorization should be selected and, more specifically, given Congress's purpose in enacting RICO, whether PLAN should fit within the category of enterprise.

As has been demonstrated, using legislative purpose to determine the scope of a regulation or statute is highly appealing in difficult cases that require an extension of a concept or a choice between two competing conceptualizations. The question remains, however, whether the use of legislative purpose can ever be justified given the problems of ascribing purpose to multi-member organizations such as Congress.

\section{THEORIES OF COLLECTIVE INTENTION ${ }^{65}$}

"In the last decade, philosophy has seen a burgeoning interest in the social world-in the nature of social relations, social entities, and sociality itself." ${ }^{66}$ Consistent with this expanding analysis of the social world, this Part describes the most significant work in the burgeoning field of collective intention. Part III.A provides a general overview of the approaches used by scholars in this area; Parts III.B-D explores the

${ }^{62}$ Id. at 262 .

63 Clark D. Cunningham et al., Plain Meaning and Hard Cases, 103 YALE L.J. 1561 (1994) (reviewing LAWRENCE M. SOLAN, THE LANGUAGE OF JUDGES (1993)).

${ }^{6}$ Id. at 1595 .

${ }^{65}$ Although I use Searle's term of collective intention, see John R. Searle, Collective Intentions and Actions, in INTENTIONS IN COMMUNICATION 401, 401 (Philip R. Cohen et al. eds., 1990), I do so neutrally.

${ }^{66}$ Frederick F. Schmitt, Socializing Metaphysics: An Introduction, in SOCIALIZING Metaphysics: The NATURE OF Social REAlity 1, 1 (Frederick F. Schmitt ed., 2003); see also, e.g., Christopher Kutz, The Collective Work of Citizenship, 8 LEGAL THEORY 471, 472 (2002) ("Clearly, liberal theory's dependence on an individualistic conception of agency comes at the cost of significant distortion of the actual framework of social life, which is so often essentially collective."). 
work of Raimo Tuomela, Margaret Gilbert, and Philip Pettit, respectively.

\section{A. An Overview of Collective Intention}

The study of collective intention is the study of whether and how groups form intentions. ${ }^{67}$ While what it means for an individual to have an intention may not itself be free from controversy, the subject becomes even more fraught with difficulty when groups of individuals are considered. Clearly, speakers of English speak as if groups are entities capable of intentions and actions. For example, it is perfectly natural to speak of a club planning an event or a company designing a new product. Although both describe situations which require more than one individual to perform separate actions, it seems quite felicitous to speak of the organization as working as a unit toward a collective goal.

In providing an overview of theories of collective intention, the first distinction to be made is between individualist accounts of collective intention and nonindividualist, or holistic, accounts. While it is virtually undisputed that the actions of individuals determine the existence and nature of social collectivities (social groups supervene on an individual's actions), ${ }^{68}$ the dispute over individualism centers on whether group intentions can be reduced to individual intentions. ${ }^{69}$ When an individual claims that a group intends to do something, does this just mean that each individual within the group has the proper intention?

Individualist accounts, such as Seumas Miller's account, describe joint action as the sum of individual actions "directed to the realisation of a collective end." ${ }^{70}$ The collective end must also be each indi-

${ }^{67}$ For a good exposition of the literature, see Schmitt, supra note 66, at 1-37, and

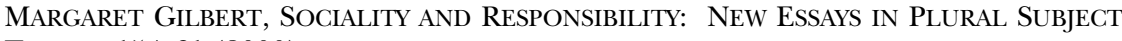
THEORY 154-61 (2000).

${ }^{68}$ See Schmitt, supra note 66 , at 2 (" $[\mathrm{S}]$ ocial relations and collectivities are determined by individuals and their nonsocial properties [in that] social relations and collectivities supervene on nonsocial properties of individuals.").

${ }^{69}$ An eliminative individualist, however, would deny the existence of social groups entirely. See id. at 6-7 (describing the theory of eliminative ontological individualsm). Schmitt's own theory of group intention is eliminativist; he concludes that joint action requires a supraindividualist account (that groups are themselves intentional subjects on par with individuals) which, in turn, prohibits the existence of any such groups. Frederick F. Schmitt, Joint Action: From Individualism to Supraindividualism, in SOCIALIZING METAPHYSICS, supra note 66, at 129, 156.

${ }^{70}$ Seumas Miller, Social Action: A Teleological Account 57 (2001). 
vidual's desired outcome. ${ }^{71}$ In addition to the actions performed by each individual, the participants in the joint actions must hold certain beliefs about the other participant's actions. ${ }^{72}$

Michael Bratman holds a similar view, which is "broadly individualistic in spirit." ${ }^{73}$ Bratman begins his discussion of shared intention with the observation that a shared intention requires more than two individuals with identical intentions. ${ }^{74}$ If you and I both intend to paint the house independently of the other's actions or intentions, we cannot properly be said to have a shared intention. Shared intention is "a state of affairs consisting primarily of appropriate attitudes of each individual participant and their interrelations," individual holds an intention that the group behave in a certain way coupled with the appropriate reflexivity of belief. ${ }^{76}$ This state of affairs allows the coordinated activity and planning that characterizes a social group. ${ }^{77}$ For Bratman, the shared intention is not an attitude; it is a state of affairs.

In Bratman's view, a shared intention means that I intend that we J. But how can "I intend our activity?" T8 The difficulty is that two individuals must come jointly to intend something where both seemingly have the exclusive power to settle the collective course of action. Bratman responds by recognizing a kind of "temporal asymmetry" wherein, for example, I form the intention that we J on the assumption that this will cause you to also come to intend that we J. "[Y] ou and I each might arrive at intentions that we J as part of a web of intentions ...." ${ }^{80}$ I realize that you are free to not intend that we J, but predict that you will and base my intention on that prediction. Thus,

${ }^{71} I d$. at $57-58$.

${ }^{72}$ See id. at 59 (“[C]ollective ends include mutual true belief.").

${ }^{73}$ Michael E. BRATMAN, FACES OF INTENTION: SElected ESSAYS ON INTENTION AND AGENCY 129 (1999).

${ }^{74} I d$. at $110-11$.

${ }^{75}$ Id. at 111 .

${ }^{76}$ Note that Bratman does not claim that his conditions are necessary for all types of shared intention, but that this is a coherent view. See id. at 160 ("[M]y concern here [has been] ... to defend the coherence of [my] conditions as at least constituting an important kind of shared intention.”).

77 See id. at 140 (describing "a social-psychological web of interlocking attitudes" as part of a strategy to defend the shared intention thesis).

${ }^{78} I d$. at 145 .

79 Id. at 157 .

${ }^{80}$ Id. (italics added). 
the shared intention is "up to each of us." ${ }^{81}$ Finally, Bratman posits a special kind of group activity called "shared cooperative activity."

Unlike Miller and Bratman, both of whom are clearly individualists, Raimo Tuomela's work is less clearly individualistic. While Margaret Gilbert ascribes an individualistic account to Raimo Tuomela, ${ }^{83}$ Frederick Schmitt argues that Tuomela's "we-mode" is not reducible to individual attitudes. ${ }^{84}$ Tuomela seems to accept, however, the idea that phenomena can be explained in individualistic terms ${ }^{85}$ and ascribes to an ontological individualism. ${ }^{86}$ Regardless, his "conceptual framework... is compatible with doctrines postulating the existence of social wholes." ${ }^{87}$

The second set of collective intention theories can be characterized as nonindividualist. For these philosophers, "[c]ollective intentional behavior is a primitive phenomenon that cannot be analyzed as just the summation of individual intentional behavior." ${ }^{88}$ John Searle and Margaret Gilbert are two proponents of nonindividualism. As an example, Searle contrasts two situations: one in which a person is running towards a shelter in a park to avoid a sudden rainstorm; the other in which a person is running towards the same point as part of an outdoor ballet. From an external point of view, both actions may appear identical. ${ }^{89}$ In the first case, "it seems no set of intends, even supplemented with beliefs about other I intends, is sufficient to get to the we intend." ${ }^{90}$ Furthermore, in the second case, the $I$ intend is derivative from the we intend; individual intentions derived from collective intentions may have different content from the collective inten-

81 Id.

${ }^{82} I d$. at 106. Bratman describes the features of shared cooperative action as including mutual responsiveness (of both intention and action), commitment to the joint activity, and commitment to mutual support. Id. at 94-95. He also notes that shared cooperative action is "cooperatively neutral" in that "joint performance of an act . . may be cooperative, but it need not be." Id. at 96-97. Examples of cooperative acts include painting a house or shoveling snow from a sidewalk, as opposed to participating in a competitive endeavor such as chess.

${ }^{83}$ GiLBERT, supra note 67, at 159.

${ }^{84}$ Schmitt, supra note 66 , at 14.

${ }^{85}$ See TUOMELA, supra note 2, at 361-63 (discussing conceptual individualism).

${ }^{86}$ See id. at 367 ("While I accept the 'intentional existence' of social wholes, viz., that concepts of social wholes can and do exist in people's thoughts, they have no real existence, viz., existence outside the realm of thoughts.").

${ }^{87} \mathrm{Id}$. at 376.

${ }^{88}$ Searle, supra note 65 , at 401.

${ }^{89}$ Id. at 403 .

Id. (italics added). 
tion. $^{91}$ We-intentions, for Searle, contain a notion of cooperation $^{92}$ and, while residing solely in the mind of the individual, make reference to the collective. The individual will have the intention: "I am doing act $B$ as part of our doing act $A .{ }^{93}$

Similarly, Gilbert's account invokes the notion of a "joint commitment" that "is not a conjunction of the personal commitments of the various parties but the commitment of all." ${ }^{94}$ Furthermore, she argues that "people share an intention if and only if they are jointly committed to espouse a certain intention as a body." 95

A further distinction can be made between internally and externally holistic (or nonindividualist) theories. ${ }^{96}$ An internal holist's account of shared or collective intention requires only that the participants in the action see the action as being an action of the group of which they are a member. ${ }^{97}$ Gilbert, in contrast, is an external holist because her account "irreducibly ascribes" the action in question to a group of individuals. ${ }^{98}$ To form a plural subject properly, individuals must jointly intend; it is not enough that each individual believe she is acting collectively or possess an intention collectively.

Unlike Gilbert, Searle is an internal holist; under his account it is the participants who ascribe the action to the group. ${ }^{99}$ In contrast to Bratman's individualist theory, Searle's theory is not an account of a state of affairs; it is an account of a certain kind of intention that an individual mind possesses. What allows us to have collective intentions is a background belief that other individuals are like ourselves and have a similar awareness of our agent status and that we view each other as possible collective agents. ${ }^{100}$ Thus, in contrast to Gilbert's external holist view (and Bratman's individualist view), Searle's account will hold "even if [the participant is] a brain in a vat" and completely

${ }^{91} I d$. For example, the collective intention may be to bake a cake, but the individual, derivative intention may be that I will crack the eggs and put them into the batter.

${ }^{92}$ See id. at 406 ("The notion of a we-intention, of collective intentionality, implies the notion of cooperation.").

${ }^{93} I d$. at 407.

${ }^{94}$ GILBERT, supra note 67, at 158.

${ }^{95} \mathrm{Id}$.

${ }^{96} I d$. at 157.

${ }^{97} \mathrm{Id}$.

${ }^{98} I d$. at $157-58$.

99 See Searle, supra note 65, at 402-03 (describing how actions take on a new character based on an individual's perceptions).

${ }^{100}$ See id. at 414 ("Collective intentionality... presupposes a sense of others as more than mere conscious agents ....”). 
mistaken as to whether the collective intention is shared. ${ }^{101}$ In such a case, not only will an individual hold a mistaken belief about the collective intention, but she will also be mistaken as to what she is doing. ${ }^{102}$

The final variety of collective intention is supraindividualism. Philip Pettit advocates a kind of supraindividualism for "certain collectivities ... [which are] subjects in their own right, giving them a way of being minded that is starkly discontinuous with the mentality of their members." ${ }^{103}$ Pettit's account does not conflict with the requirement that collectivities must supervene on individual actions; it merely says that once certain collectivities come into existence, they "assume a life of their own... displaying all the qualities expected in personal agents." 104

Most philosophers of collective intention have focused primarily on small groups, often with just two members. ${ }^{105}$ I now go on to describe in more detail the work of the three philosophers who most clearly address the intricacies of structured social groups and whose work holds the most potential to be fruitfully applied to Congress: Raimo Tuomela, Margaret Gilbert, and Philip Pettit. Because of the particular complexities that Congress poses for these theories, this Part highlights the work of philosophers of collective intention who have focused on the intention forming of larger groups.

\section{B. Raimo Tuomela}

Tuomela's account of collective intention makes a fundamental "distinction between the notions of having an attitude or acting as a group member versus as a private person." 106 These he calls the "we-mode" and the "I-mode." 107 The notion of joint intention, for Tuomela, requires the "we-mode" and "we-intentions." Tuomela defines we-

101 Id. at $407,414$.

102 Id. at 408.

103 Philip Pettit, Groups with Minds of Their Own, in SOCIALIZING METAPHYSICS, supra note 66 , at 167,167 .

104 Id. at 191.

105 See Annette C. Baier, The Commons of The Mind 26 (1997) ("Yet when recent philosophers such as John Searle and Michael Bratman have turned their attention to collective intention and collective action, they have chosen pairs of persons, and so have seen the collective intention as no more than the coordination of two individuals' intentions.").

106 Raimo Tuomela, The We-Mode and the I-Mode, in SOCIALIZING METAPHYSICS, supra note 66 , at 93,93 .

107 Id. 
intentions thus: " $A$ we-intends to bring about $X$ [if and only if] $A$ shares the (agreement-based) intention to bring about $X$ and believes that this intention to bring about $X$ is shared in $G$ and believes that it is mutually believed that this intention is shared in $G \ldots .$. "108 A more recent formulation introduces the idea of the group's "collective acceptance" of the intention in place of the mutual belief: "[I]f a group collectively accepts something as its view, it binds itself to this view and this involves a kind of group pressure ...."109 Furthermore, this formulation of the central we-mode requires that an individual is functioning as a group member and is committed to the action at least in part because of the group. ${ }^{110}$ To function as a group member is to "intentionally attempt to act in a way related to ... the group's realm of concern such that [it] does not violate the group's central, constitutive goals, beliefs, standards, and norms . ..."111

Joint intentions, for Tuomela in The Importance of $U s,{ }^{112}$ require the making of an agreement. ${ }^{113}$ This agreement need not be a recurring agreement. Tuomela argues that "especially in institutionalized social settings ... there can be standing joint intentions (policies) which are activated in suitable circumstances but which do not presuppose renewed intention-formation or renewed agreement-making." ${ }^{114}$ These "standing joint intentions" rely on social norms which participants enter into when they join the institution in question.

Building on this relaxed notion of agreement, Tuomela further refines his definition of a we-intention. Tuomela discusses types of joint action, including "noncooperative joint action" where participants cooperate only in so much as they fulfill their agreement. ${ }^{115}$ The participants do not help the other participants move fully towards their goals; rather, the "agents act on their part-related preferences (utilities) built into the structure of the action." 116

${ }^{108}$ TUOMELA, supra note 2, at 38 (italics added).

109 Tuomela, supra note 106, at 103.

${ }^{110} I d$. at 104.

${ }^{111} I d$. at 100.

112 The book is a highly complex and intricate work, which I have attempted to summarize (and simplify) here. For a more recent exploration of these issues, see Raimo Tuomela, The Philosophy of SOCial Practices: A Collective ACCEPTANCE VIEW (2002).

113 TUOMELA, supra note 2, at 74 .

${ }^{114} I d$.

115 Id. at 149.

${ }^{116} I d$. 
Finally, Tuomela discusses the idea of group goals, which in turn amount to group intentions. ${ }^{117}$ Understanding group intentions requires separating "operative" from "nonoperative" members of a group. Operative members are those members whose actions lead to group action or those whose actions set the intentions for the group. ${ }^{118}$

Tuomela gives the example of a state which intends to form a peace treaty. The appropriate collective members may draft the treaty and sign it; these are the operative members. While most citizens have done nothing to directly participate, the state can act as a collective whole if the citizens were in some way obliged to accept the officials acting on their behalf. ${ }^{119}$ "The nonoperative members may disagree with the goal formed for $G$, but typically they can still be assumed to conform to what the operative members do, and in this sense to 'tacitly' or 'weakly' accept their joint goals as valid goals of G." ${ }^{120}$ According to Tuomela, there is at least a prima facie duty on the part of the nonoperative members to accept these goals when they are acting within a structured social group where the operative members are acting within the relevant authority system. ${ }^{121}$ This formulation is "compatible with there being nonoperative members who even qua members of $G$ disagree with the ... goals of the operational members."

\section{Margaret Gilbert}

As described in Part A, Margaret Gilbert can be characterized as an external holist. ${ }^{123}$ Gilbert proposes three criteria of adequacy for a

${ }^{117} I d$. at 285 .

${ }^{118}$ Id. at 273-74.

${ }^{119} I d$. It is debatable, of course, whether citizens would be obliged to accept the decision. See generally Heidi M. Hurd, Challenging Authority, 100 YALE L.J. 1611 (1991) (examining the foundations of legal authority). Note also that operative members vary from group task to group task. TUOMELA, supra note 2, at 274.

${ }^{120}$ TUOMELA, supra note 2, at 276 (italics added).

${ }^{121} I d$. at 281.

${ }^{122}$ Id (italics added).

${ }^{123}$ It seems that Gilbert sees her task as primarily conceptual. See Margaret Gilbert, What Is It for Us To Intend?, in 2 CONTEMPORARY ACTION THEORY 65, 66 (Ghita Holmstrom-Hintikka \& Raimo Tuomela eds., 1997) ("What is it for us to share an intention? In this essay I propose an answer to this question. I take the question to call for an analysis of the everyday concept of a shared intention."). At points, she appears to be making ontological claims: "people form a plural subject of $X$-ing if they are jointly committed to $X$ as a body." GILBERT, supra note 67 , at 158. As Gilbert writes in On Social Facts, "[g]iven that it is clear what plural subjects amount to, one can decide 
shared intention: obligation, the view that whenever one understands a shared intention to exist, one also understands an obligation to fulfill one's end; permission, the view that a participant in a shared intention is understood to require the permission of the other to change the plan; and "compatibility with lack of the corresponding personal intentions," which is the view that a shared intention does not require a matching personal intention. ${ }^{124}$

A shared intention, for Gilbert, requires a plural subject that comes into being when individuals are jointly committed to performing some action as a body. For shared intention, this means that the individuals are jointly committed to intending as a body. ${ }^{125}$ Intending as a body is "all acting in such a way as to constitute a body that" intends. ${ }^{126}$ Joint commitment means a commitment of two or more people; a joint commitment is not the sum of two personal commitments, but a holistic commitment held by two or more people that results in dependent individual commitments. ${ }^{127}$ A joint commitment comes into being when the participants exhibit "matching expressions of personal readiness to enter a particular joint commitment." 128 The shared intention provides a single motivating force for all the individuals, and, thus, personal intentions would be redundant. ${ }^{129}$

In On Social Facts, Gilbert notes that for some actions and types of groups (for example, one country invading another) certain representatives can "speak for" the entire group. This works when "members of the group jointly accept that certain decisions of a certain few are to count as our decisions." ${ }^{130}$ Furthermore, Gilbert discusses how a group can jointly accept a particular principle, while individuals may still diverge in their personal views:

\footnotetext{
on their reality in the light of one's own ontological preferences." MARGARET GILBERT, ON SOCIAL FACTS 432 (1989). After giving the example of seeing two people chatting and claiming they are a plural subject:

I take it that they have... the concept of a plural subject. Why should one deny of them that once they have fulfilled the conditions, they constitute such a subject? The only reason I can see, is if one has an ontology which is more or less restricted to stones. 
One is required to express the jointly accepted view only in the appropriate circumstances....

... [O]ne may be able to carry out the obligations inherent in one's joint acceptance of a principle while not only personally endorsing a contrary principle, but actually conforming to a personal principle at certain times. ${ }^{131}$

Under this view, then, the joint commitment to act or believe in a certain way is not undermined by contrary personal views, as long as the individual has jointly accepted the view.

\section{Philip Pettit}

In some ways, Pettit's account of shared intention can be seen as the most extreme. He argues that certain collectivities "assume a life of their own ... displaying all the qualities expected in personal agents." ${ }^{132}$ This view may be described as ontological supraindividualism. ${ }^{133}$ Pettit begins his article by discussing a paradox that can arise in group decision making. ${ }^{134}$ Most such decisions are conclusioncentered in that individual votes are taken on the final result; however, it may be the case that counting each individual's vote on each portion of the decision (acting premise-centered) will lead to a different result. ${ }^{135}$ Pettit also describes a diachronic version of the problem where a group must decide whether to base their decision on the current issue or on premises culled from their prior decisions. ${ }^{136}$ As Pettit views it, groups face a choice: they may respond to individual views, running the risk of being inconsistent over time, or they may choose to reason as a collective "even where that means compromising responsiveness to the views of individual members."

131 Id. at 375 .

${ }^{132}$ Pettit, supra note 103, at 191.

${ }^{133}$ See Schmitt, supra note 66, at 15 (describing ontological supraindividualism as "the view that the entities that we are talking about when we speak of groups . . in fact exist").

${ }^{134}$ Pettit, supra note 103, at 168-72.

${ }^{135}$ For example, Pettit describes a tort action decided by three judges. While only one judge might find both causation and duty of care (and, therefore, liability), a majority of the judges might believe the defendant's actions caused the harm and a majority might also believe there was a duty of care. Id. at 168. Pettit bases this example on the argument in Lewis A. Kornhauser \& Lawrence G. Sager, Unpacking the Court, 96 YALE L.J. 82, 115 (1986).

${ }_{136}$ Pettit, supra note 103, at 172-73.

${ }^{137}$ Philip Pettit, Collective Persons and Powers, 8 Legal TheORY 443, 450 (2002). 
"[P] urposive groups," as Pettit describes them, are groups that "coordinate their actions around the pursuit of a common purpose" and these groups will have to make decisions about how they are to act. ${ }^{138}$ Over the course of its existence, a group or organization will make decisions about courses of action and will build up a record of such decisions. These past decisions will constrain the future actions of the group; the group will eventually confront the dilemma described above: they will have to decide whether to act consistently with their past decisions. ${ }^{139}$ Many organized groups will choose to conform with past decisions in order to project an image of consistency. These groups "that collectivize reason," he argues, "deserve ontological recognition as intentional and personal subjects." ${ }^{140}$ Pettit calls these social integrates. ${ }^{141}$

According to Pettit, social integrates can be considered intentional subjects because they "display all the functional marks of an intentional subject." ${ }^{142}$ The group will "generally act in a manner that is rationalized by independently discernible representations and goals .... [I]t will display the degree of constancy as well as the degree of coherence that we expect in any intentional subject." ${ }^{43}$ Pettit goes on to claim that social integrates are institutional persons capable of being held to task for inconsistency in judgments and intentions. ${ }^{144}$

Having summarized the most influential thinkers and accounts in collective intention, I now turn to how their accounts may be fruitfully applied to the social group in question: Congress. I first examine the nature of Congress as a social group and which, if any, of the above accounts allow us to infer shared intentions on the part of Congress. Section IV.F then considers the limits of these inferences in terms of the scope of mental states attributable to Congress.

${ }^{138}$ Pettit, supra note 103, at 176.

${ }^{139} I d$.

${ }^{140} I d$. at 175 .

${ }^{141} I d$. at 178.

${ }^{142} I d$. at 182. Note that Pettit's account does not address the nature, if any, of the shared intention or subjecthood of a group which fails to meet his criteria for social integrate.

${ }^{143} I d$. See Kornhauser \& Sager, supra note 135 , at $116-17$, for a discussion of consistency versus coherence.

${ }^{144}$ Pettit, supra note 103 , at 185. 


\section{CONGRESS AND COLLECTIVE INTENTION}

Congress as a social group ${ }^{145}$ poses particular problems for a theory of collective intention. Because it is beyond the scope of this Comment to argue effectively for or against one of the approaches to collective intention described in Part III on a rigorous philosophical basis, ${ }^{146}$ my argument here is the more limited one: that despite Congress's complexity, a theory of Congress as an intentional entity is plausible using at least one account of collective intention. First, I review several prior attempts in the legal literature to defend legislative intent using theories of collective intention. Then, I put forth my positive argument for why legislative intent is possible: why Congress can be said to be an entity with intentions. ${ }^{147}$

\section{A. Previous Defenses of Legislative Intent}

Lawrence Solan, in Private Language, Public Laws: The Central Role of Legislative Intent in Statutory Interpretation, argues effectively that speaking of legislative intent is a coherent and virtually unavoidable thing for judges to do. ${ }^{148}$ Even in a case where almost no legislator had an intention toward the legislation that was passed, a "judge's remark [about the intent of the legislature] is both natural and coherent." ${ }^{149}$ This reference is unavoidable because, Solan argues, the group adopts the statements of a subgroup, be it a committee or a group of members of Congress. ${ }^{150}$ Members of Congress can have different reasons for supporting the bill as long as they recognize that those who developed the legislation had appropriate plans for the

${ }^{145}$ I assume that Congress forms a social group. See Solan, supra note 27, at 438-39, for an interesting discussion of how we form perceptions of individuals as groups.

${ }^{146}$ Note, for example, the stringent criticism that supervenience without reducibility has evoked in philosophy of mind. See Jaegwon Kim, The Myth of Nonreductive Materialism, in THE MIND-Body PROBlem 242, 250-53 (Richard Warner \& Tadeusz Szubka eds., 1994) ("[S] upervenience is not going to deliver to us a viable form of nonreductive materialism ...."). An analogous criticism for collective intention would preclude any nonindividualist account.

${ }^{147}$ This argument leaves open two possibilities, which this Comment does not resolve: 1) Congress's intent may be unknowable for pragmatic reasons in many cases, and 2) while Congress's intent does exist, it may be irrelevant for statutory interpretation.

${ }^{148}$ See Solan, supra note 27, at 444-47, for examples of justifications of legislative intent.

Id. at 445 .

${ }^{150}$ Id. at 447. 
bill. ${ }^{151}$ "All of this means that when judges speak of legislative intent, and attribute reasons to the legislature as though it were a single individual with a mind of its own, they are simply doing what we all do when we talk about deliberative groups." ${ }^{\text {"152 }}$ Furthermore, once we begin to treat collective entities as individuals, we will attribute the trait of volition to those entities. It is "common and coherent to understand plural subjects as having beliefs, intentions, and other states of mind." 153

Solan has presented a convincing conceptual account. Surely it is true that we (including judges) speak as though Congress were a singular entity capable of intentions, ${ }^{154}$ and most of us believe that these statements are accurate. Even textualist judges refer to the intent of Congress on occasion, thus recognizing, to some extent, that Congress must be an entity with collective intentions. ${ }^{155}$

The problem, as I see it, is that under this account (and in this regard the account is similar to Gilbert's) the recognition of collective entities may in some cases be wrong. Even though a certain account of group behavior motivates the use of we, does that mean that all felicitous uses of we allow all the same inferences or are there finer distinctions to be made among different types of groups? Even if we are satisfied with a purely conceptual account (or we believe a conceptual account is an ontological account), is it possible that we assume Congress has certain properties making it justifiably conceived of as a plural subject, when it really does not? In order to justify inferences from the actions of Congress, one must first outline the difficulties the nature of Congress poses to an account of collective intention and see if any account of collective intention can support looking to legislative intent. If so, what kind of inferences can be justified? Is Congress actually enough like an individual (or an undisputed we-subject) to infer intentions about the words of a statute? What about inferring purposes and desires?

Other legal scholars have used the philosophy of collective intention. For example, Anderson and Pildes, in Expressive Theories of Law:

151 Id.

${ }^{152}$ Id. at 449; see also id. at 449-53 (reviewing the psychological literature explaining why and how we come to attribute states of mind to groups).

Id. at 453 .

154 See, e.g., John Breaux, Congress Is at War with Itself!, PHILA. INQUIRER, Nov. 7, 2004, at C1 (illustrating the personification of Congress).

${ }^{155}$ See Solan, supra note 27, at 38-44 (demonstrating that even textualists rely on the language of intent in their opinions). 
A General Restatement, use the work of Margaret Gilbert to justify collective intention; however, they do not apply the theory directly to Congress. ${ }^{156}$ Sinclair, in Legislative Intent: Fact or Fabrication?, criticizes Eskridge and seems to side with a nonindividualist account of collective intention. ${ }^{157}$ Finally, Professor Tiefer uses the work of Austin and Searle to account for collective intention. ${ }^{158}$ While each of these articles presents interesting analyses of part of the literature, I would like to present a broader, more rigorous comparison of the theories of collective intent and their application to Congress.

\section{B. What Is Unique About Congress?}

Given that at least one account of collective intention is plausible, there are at least some circumstances under which one can accurately speak of shared intentions. What is it about Congress that makes it such a challenging case? First, Congress has unique characteristics as a social group: it has hundreds of members, divided into two houses, both of which must approve legislation. ${ }^{159}$ While only legislators can introduce bills, the bills are often drafted in substantial part by the executive branch or private individuals or organizations. ${ }^{160}$ Most bills are then referred to smaller committees in the House of Representatives or the Senate and then reported from the committee. ${ }^{161}$ These committees have a great deal of control over what legislation reaches the floor. ${ }^{162}$

If the bill does not die in committee, a report is sent to the full legislative chamber; the committee report contains the background of the bill, the bill's exact language, and an analysis of the bill. ${ }^{163}$ "Com-

${ }^{156}$ Anderson \& Pildes, supra note 28, at 1514-24.

${ }^{157}$ Sinclair, supra note 28, at 1351-57. Note that Sinclair does, at one point, cite Bratman. Id. at 1354

${ }^{158}$ Tiefer, supra note 28, at 259-64.

159 See William N. ESKRIDGE, JR. ET AL., CASES AND MATERIALS ON LEgiSlation: Statutes AND the Creation of Public Policy 24 (3d ed. 2001) (describing Congress's bicameralism and presentment requirements and their effects on the legislative process).

${ }^{160}$ Id. at 26.

161 See BARBARA Sinclair, UNORTHOdOx LAWMAKING 15 (2d ed. 2000) (stating that in the 104th and 105th Congresses only one in ten bills in the House of Representatives bypassed a committee); $i d$. at 37 (stating that for the 104th Congress, only one in four bills bypassed the Senate committee stage).

${ }^{162}$ See ESKRIDGE ET AL., supra note 159, at 28 ("No more than one in ten bills becomes law, and most of the unsuccessful proposals are killed in committee.").

${ }^{163}$ Id. at 30 . 
mittee reports ... are frequently the only documents that most legislators and their staffs will read before a vote is taken on the bill., ${ }^{164}$ Following the report, informal "postcommittee adjustments" are often made. ${ }^{165}$

Once the report is issued, the bill is placed on a legislative calendar. ${ }^{166}$ Once the bill is on the agenda, floor consideration occurs. While "[f]ew votes appear to be altered by floor debate," floor consideration also includes the process of amending the bill, which can be quite intense for major legislation. ${ }^{167}$ The amendment process is frequently governed in the House by special rules, ${ }^{168}$ which can also modify the order in which bills are presented and the time allowed for debate. ${ }^{169}$ These rules can be used to "structure the choices members confront on the floor in a way that promotes a particular outcome."170

Similarly, the Senate often operates under "a formal unanimous consent agreement (UCA)." ${ }^{171}$ The UCA limits debate and amendments and may bar nongermane amendments; as the name suggests, the support of such a rule must be unanimous. ${ }^{172}$ After debate and amendments, members of Congress vote on the bill. The entire process leading up to the vote has become increasingly less "textbook" and, as Barbara Sinclair describes, more "unorthodox": "Now variation is the norm ... if one route is blocked there is always another to try." 173

If the House of Representatives and the Senate vote to approve different versions of similar bills, a conference committee is formed. ${ }^{174}$ In practice, members of the original committee appoint members to this conference committee. ${ }^{175}$ Following the conference committee, a new report is issued that sets forth the propositions agreed to by the

164 Id.

165 See SINCLAIR, supra note 161, at 17 ("[M] ore than a third of major legislation [is] subject to such postcommittee adjustments in most recent Congresses . . ..”).

166 ESKRIDGE ET AL., supra note 159 , at 31.

${ }^{167}$ Id. at 33-34.

${ }^{168}$ The House and Senate are given this power in the Constitution. U.S. CONST. art. I, $\S 5$, cl. 2 ("Each House may determine the Rules of its Proceedings, punish its Members for disorderly Behaviour, and, with the Concurrence of two thirds, expel a Member.").

169 SINCLAIR, supra note 161 , at 21.

170 Id. at 24 .

171 Id. at 45 .

172 Id.

${ }^{173} I d$. at 34 .

174 Id. at 57.

${ }^{175}$ Id. at 60. 
committees. Both houses then vote to accept or reject the conference bill. $^{176}$ As the reliance on committees both pre- and post-floor consideration suggests, "Congress has a complex and detailed division and specialization of labor in which each chamber gives disproportionate agenda power to specific subsets of legislators ...." ${ }^{177}$ Thus, only certain small groups of legislators have positions of great control over the content of legislation.

Second, members of Congress vote on legislation for varying reasons, often having little to do with their careful consideration of the issue being legislated. ${ }^{178}$ These members of Congress may not have formed a personal intention that the legislation pass. In highly controversial cases, many members of Congress vote against the legislation, thereby evincing their personal intention that the legislation not pass. Furthermore, even members of Congress who vote in favor of legislation may have a contrary personal intention that the legislation not pass. ${ }^{179}$ Thus for many reasons, members of Congress may not have a personal intention, based on the substance of the statute, that the statute be passed. This calls into question whether Congress as a group can be said to have intentions.

Third, unlike the cooperative participants most often described in the literature on collective intention, members of Congress may be openly hostile to one another and seek to undermine the success of other members' proposed legislation. ${ }^{180}$ Furthermore, politically powerful groups in Congress may break Senate or House rules or attach measures to bills that cannot be thrown out without grave consequences (e.g., an appropriations bill) in order to force their opponents to vote in favor of the measures. ${ }^{181}$

Finally, Congress's actions are of a unique type. Congress is not simply attempting to bake a cake or run a football play or even dance an outdoor ballet. Congress's function (at least in the sense relevant

${ }^{176} I d$. at 57 . Both chambers must approve bills with identical wording. Id.

${ }^{177}$ Shepsle, supra note 25, at 245.

${ }^{178}$ See ESKRIDGE, supra note 25, at 16 (identifying reasons legislators vote for bills, such as to support legislation the President, party leaders, or relevant interest groups favor).

${ }^{179}$ See, e.g., id. (noting that legislators sometimes vote for a bill because others whom they wish to support favor a bill).

${ }^{180}$ See, e.g., ESKRIDGE ET AL., supra note 159, at 34 (describing how members of Congress can introduce "killer amendments" which appear friendly but are designed to kill the bill by "antagoniz[ing] the bill's more moderate supporters").

${ }^{181}$ See, e.g., Edward R. Becker, Of Laws and Sausages, 87 JudicATURE 7,9 (2003) (providing examples of additions to appropriations bills). 
here) is as a legislative body: passing, amending, and rescinding statutes. A text is created when Congress passes or amends a statute, but it is not an ordinary text like a shopping list or essay: the act of passing a statute is a "performative utterance" or "performative speech act," that is, one which changes the world in some way. ${ }^{182}$ For example, when an employer says "you're fired," she has communicated a message, but has also changed the state of the world. Unless the utterance misfires because she lacks the relevant authority, you are, in fact, no longer in her employ. The same is true for the passing of statutes: meaning and action intertwine. Congress's intent, then, is what the words convey and that, in turn, changes a state of affairs in the world. The collective intentions we are concerned with are those directed at the performative utterance of enacting a statute.

The text that is passed differs from many other kinds of texts for another reason. In Tiersma's terms, a statute is a kind of "autonomous text." ${ }^{183}$ The text has been "textualized" by "a legislature . . . empowered to textualize its intentions." ${ }^{184}$ This textualization "guarantees that the text is not just authoritative, but is the complete expression of the legal actor's intent." ${ }^{185}$ Tiersma writes that "[s] tatutes are, in fact, not unlike messages set adrift in the currents of the ocean," ${ }^{186}$ because "an autonomous text tends to be written so it can be interpreted without reference to outside sources-in other words, without additional knowledge of who the writer was, the circumstances, or the purpose of the writing. All relevant information, to the extent possible, is contained in the writing itself." ${ }^{187}$ Members of Congress know that their statutes are performative acts and that they will be inter-

${ }^{182}$ See Dennis Kurzon, It Is Hereby Performed . . .: Ex Exlorations in Legal SPEECH ACTS 5-24 (1986) (analyzing statutes as performative speech acts); Tiefer, supra note 28, at 256-57 (discussing Austin's analysis of speech that has an operative effect). For a description of performatives, see generally J.L. Austin, How To Do THINGS WITH Words 1-11 (1962); GENNARO CHIERCHIA \& SAlly MCCONNELl-GINET, MEANING AND GRAMMAR 220-39 (2d ed. 2000); John R. Searle, How Performatives Work, in EssaYs IN SPEECH ACT THEORY 85, 85-107 (Daniel Vanderveken \& Susamu Kubo eds., 2002). Cf. John R. SEarle, Expression and Meaning: Studies in the Theory of Speech ACTS 16-20 (1979) (employing an outdated syntactic analysis).

${ }^{183}$ Tiersma, supra note 31 , at 482.

${ }^{184}$ Peter M. Tiersma, From Speech to Writing: Textualization and Its Consequences, in LANGUAGE AND THE LAW 349, 360 (Marlyn Robinson ed., 2003).

${ }^{185} I d$. at 359.

${ }^{186}$ Tiersma, supra note 27 , at 433 . Tiersma also includes an interesting history of how statutes came to be more autonomous, beginning with medieval judges who commonly had no authentic text available to them and felt free to ask members of parliament what was meant by a statute. Id. at 435-43.

${ }^{187}$ Id. at 448. 
preted without access to each legislator's state of mind at the time of writing; thus, statutes are textualized in Tiersma's sense.

\section{Is Congress an Institutional Person?}

To begin the inquiry into the possibility of collective intent on the part of Congress, I first begin with the most extreme claim: that Congress is an institutional person in the sense that Pettit describes. ${ }^{188}$ This view does seem to be present in Supreme Court opinions. For example, in FDA v. Brown $\mathcal{E}$ Williamson Tobacco Corp., the Court determined that "Congress intended to exclude tobacco products from the FDA's jurisdiction," because if Congress had not so intended, the FDA would be required to ban them from the market. ${ }^{189}$ Congress had, subsequent to granting jurisdiction to the FDA, demonstrated an intent to regulate, instead of ban, tobacco products; the forced withdrawal of tobacco products from the market would contradict this intent. ${ }^{190}$ Justice O'Connor looked to the statutes Congress had enacted over a thirty-five -year period and concluded that "a specific policy embodied in a later federal statute should control our construction of the [earlier] statute, even though it ha[s] not been expressly amended." 191

This approach to understanding statutory interpretation is perfectly reasonable, if one can conceive of Congress as an institutional person. If I say something today that you take to be unclear, but follow up with a more specific statement tomorrow, you are perfectly justified in seeking to mesh the two statements into one coherent statement because of your expectations about rational individuals. We expect a certain degree of "constancy" and "coherence" in an intentional subject. ${ }^{192}$ Is this a reasonable expectation for Congress? I think not. ${ }^{193}$ Pettit himself wonders whether a "Washington-style con-

${ }^{188}$ See supra notes 134-44 and accompanying text (describing Pettit's account of "purposive groups").

189529 U.S. 120, 140 (2000).

${ }^{190} I d$. at 143.

${ }^{191} I d$. at 143 (quoting United States v. Estate of Romani, 523 U.S. 517, 530-31 (1998) (alterations in original)).

${ }^{192}$ Pettit, supra note 103, at 182.

${ }^{193}$ I argue that we cannot legitimately have these expectations of Congress, even if this might lead to a reasonable, or even the best, outcome in a case. See infra Part IV.F. Additionally, note that the majority in Brown $\mathcal{E}$ Williamson did not rely solely on this argument. See Brown E Williamson, 524 U.S. at 121 (considering common sense in "delegat[ing] a policy decision of such economic and political magnitude to an administrative agency"). 
gress function[s] like a person" ${ }^{194}$ and notes that "depending on the procedures whereby they operate, the members of different organizational bodies in a state-say, a parliament-may or may not constitute institutional persons."

Remember that Pettit distinguishes between two types of groups: those that must be maximally responsive to their individual members' preferences and those that collectivize rationality and seek some consistency. ${ }^{196}$ According to Pettit, a group that chooses to reason as a collective "will not be an effective or credible promoter of its assumed purpose if it tolerates inconsistency or incoherence in its judgments across time." ${ }^{197}$

In contrast to Pettit's purposive groups, Congress in our representational democracy ${ }^{198}$ is understood to respond maximally to its members' views. ${ }^{199}$ In a democracy, legislation is passed by majority vote $;^{200}$ furthermore, representational democracy requires legislators to be responsive to their constituency. A member of Congress should not choose to support a policy simply because it is consistent with a past policy of a previous Congress. ${ }^{201}$ Congress's purpose is not undermined by inconsistency over time-legislative enactments may be overturned or modified as social and political views evolve.

Pettit raises one further possibility for groups like Congress. He writes that "an occasionally inconsistent parliament may still function as a person as long as there is a second body—say, a review court-

${ }^{194}$ Pettit, supra note 137 , at 467.

195 Id. at 464.

196 Pettit, supra note 103, at 175.

197 Pettit, supra note 137 , at 453.

198 Pettit's argument in favor of institutional persons as centers of governance relies on his republican view of government, which, he claims, "argues strongly in favor of having institutional persons in charge of political life." Id. at 464. This Comment cannot address the merits of republican views of government versus strict democratic views, but it is enough, I think, to note that our current understanding of Congress does not fully comport with a republican view: we understand Congress as representing citizens' views and we recognize citizens' power to affect policy by electing or removing members of Congress.

${ }^{199}$ There are, of course, constitutional and other restrictions on Congress's actions.

${ }^{200}$ See ESKRIDGE ET AL., supra note 159, at 35 ("The number of votes needed to adopt an amendment or pass a bill is normally a majority of those voting in each house of Congress, assuming a quorum is present.").

${ }^{201}$ Cf. RONALD DWORKIN, LAW's EMPIRE, 243-44 (1986) (arguing that while judges are bound to view law "by a coherent set of principles," legislatures do not "need reasons of principle to justify the rules it enacts" and are free to "create new rights" as guided by a pursuit of good policy). 
that interprets all legislative acts on the assumption that they are meant to be consistent." ${ }^{202}$ First, it is arguable that the Court always treats Congress's acts in a way that requires consistency. Second, given that the purpose of this Comment is to determine when and if the Court is justified in treating Congress as a social group with intentions or purposes, this definition of institutional person is singularly unhelpful. The argument would run as follows: "the Court treats Congress as an institutional person; therefore, Congress is an institutional person and the Court is justified in treating it as such." Thus, it seems that Congress cannot meet the criteria set out by Pettit for social integrates except in a way that begs the question of this Comment. ${ }^{203}$

\section{Is Congress as an Entity Capable of Shared Intentions?}

Given that Congress cannot be considered an institutional person, is it possible, nonetheless, that Congress can be said to have shared intentions? I believe it can. I begin by defending my statement in Part III.A that the accounts of John R. Searle and Michael Bratman cannot provide an adequate account of Congress's intent. The shortcoming in Searle's account is that it does not provide the conditions for when a person external to the group can properly say that a group has a collective intention. Because a brain in a vat could believe itself to have a collective intention, but be wrong, we need conditions for when a person is right in her beliefs. Does every participant need to have the requisite collective intention? Do the collective intentions need to be identical? Although Searle notes that in competitive or aggressive situations, the participants may only have a higher-order intention to cooperate, ${ }^{204}$ he does not in detail describe, how and to what extent, the participants can be said to share an intent. We must look further for the answers to these questions.

Although Bratman is an individualist and, therefore, believes that "I intend that we $J$ " is reducible to individual intentions contra Searle, a similar problem appears in his analysis. Although it is clear in some cases that a shared intention exists, it is not clear at what point this begins to break down. Bratman himself recognizes that he is describ-

${ }^{202}$ Pettit, supra note 137, at 468.

${ }^{203}$ I am assuming that a social integrate could exist or is, at the very least, a coherent concept.

${ }^{204}$ Searle, supra note 65 , at $413-14$. 
ing what may be only one kind of shared intention. ${ }^{205}$ If our intending is dependent on a certain back-and-forth between the individual participants, ${ }^{206}$ it seems that Congress will have trouble meeting this requirement. Members of Congress who vote against legislation will not have expressed their conditional assent to our intending to the participants who do so intend. Perhaps certain subgroups of Congress do fit this description, such that one member forms a we-intention on the assumption that the other will form one as well, but as a description of the entirety of Congress, this view is not tenable.

Furthermore, Congress fairly clearly fails Bratman's description of full-blown shared cooperative activity. Bratman presents three criteria: "mutual responsiveness," "commitment to the joint activity," and "commitment to mutual support." ${ }^{207}$ Members of Congress are not generally willing to help all other members of Congress toward a collective goal. In fact, they may be willing to undermine each other's efforts to achieve what will become the group's goals. There may be, at best, a tacit acceptance of the legislation passed. Bratman notes that some competitive activity may be something like a shared cooperative activity, but only at a very high, general level. Such an account could work for Congress, given that there are some rules to which all members abide and work cooperatively toward. Thus, while Bratman's account cannot, as it stands, adequately describe Congress, an account like Bratman's might be extended to Congress with some additions. $^{208}$

205 See BRATMAN, supra note 73, at 160 (acknowledging the possibility of other forms of shared intention, even where "neither agent, strictly speaking, intends the shared activity").

${ }^{206}$ See supra notes 79-80 and accompanying text (describing the web of intentions formed as part of the "temporal asymmetry" required for joint intentions).

${ }^{207}$ BRATMAN, supra note 73, at 94-95. This is simply a different formulation of SCA described in Part III.A.

${ }^{208}$ See Scott J. Shapiro, Law, Plans, and Practical Reason, 8 LEGAL THEORY 387, 40405 (2002), for an extension of Bratman's intentional joint activity account to situations where an individual or an individual acting in a particular capacity has authority over a group. Shapiro uses this account to argue for legal positivism. Shapiro relaxes many of Bratman's requirements to account for large groups with central authority. Id. at 412-13. While this account provides an interesting starting point for understanding authority in a legal system, it does not seem to readily extend to groups like Congress where no central authority figure issues "orders" that require another member to "adopt the content of the order as his or her subplan." Id. at 406. As Bratman himself summarizes Shapiro's account: "We each have intentions that are specifically about how certain orders of mine are to give you reasons for action." Michael E. Bratman, Shapiro on Legal Positivism and Jointly Intentional Activity, 8 LEGAL THEORY 511, 513 (2002). Again, members of Congress do not give each other orders that provide reasons for action. 
Gilbert's and Tuomela's accounts are, thus, the most promising. Both acknowledge the complications of larger organizations and both recognize that smaller groups of an organization may come to represent the group's collective intentions. ${ }^{209}$ One of Gilbert's primary criteria for a plural subject, and thus shared intention, is that it must be possible even where personal intentions are not corresponding. Thus, a member of Congress could have a personal intention quite contrary to that of the collective intention, without undermining the collective intention as such. ${ }^{210}$ How is it, though, that a member of Congress comes to accept the will of another for the collective will? What if certain members still disagree that the intention should be accepted? Remember that Tuomela goes a step further, stating that this formulation is "compatible with there being nonoperative members who even qua members of $G$ disagree with the ... goals [intentions] of the operative members." ${ }^{211}$

While I think that in principle both Gilbert and Tuomela point to the answer-that there is some higher-level or meta agreement or joint commitment-only Tuomela discusses the relevant authority system and why nonoperative members must be in some sense obliged to go along in order for it to be a proper collective intention. ${ }^{212}$ I therefore present my analysis building off the work of Tuomela. ${ }^{213}$

\section{E. A Tuomelaic Account}

In Part II.C I discussed, for the most part casually, Tuomela's claims about group intentions and how a group intention might exist even in a situation where not all members of a group held the same intention, even qua group members. I now present a modified version of Tuomela's technical requirements for a group intention:

$L$ is an intended legislative act and intended change in the state of the legal world of Congress $(G)$ in the social and normative circumstances $C$

209 See GILBERT, supra note 123, at 206 (noting that in situations where not all group members are directly involved in decision making, the decisions of a few count as the group's decision); TUOMELA, supra note 2, at 273-74 (same).

${ }^{210}$ See supra notes 178-79 for a description of the circumstances under which members of Congress can have a contrary personal intention.

${ }^{211}$ TUOMELA, supra note 2, at 281 (italics added).

${ }^{212} I d$.

${ }^{213}$ Tuomela's work may also be preferable because, while compatible with nonindividualism, it does not seem to require it. The fewer philosophical commitments, the better. 
if and only if in $C$ there are operative members $A_{1} \ldots A_{n}$ of $G$ in respective positions $P_{1} \ldots P_{n}$ such that:

(1) $L$ is intentionally jointly accepted as an intention of $G$ by the operative agents $A_{1} \ldots A_{n}$ when performing their social tasks in positions $P_{1} \ldots P_{n}$ and due to their exercising the relevant authority system of $G$;

(2) There is a mutual belief among the operative members $A_{1} \ldots A_{n}$ to the effect that (1);

(3) Because of (1), the full-fledged nonoperative members of $G$ tend to tacitly accept-or at least ought to accept- $L$ as the intention of $G$, as members of $G$;

(4) There is a mutual belief in $G$ to the effect that (3). ${ }^{214}$

Now we can see how this description fits Congress. When a bill comes up for vote, certain members of Congress will vote for a bill and others may vote against it. Only those members of Congress who were responsible for the bill's drafting, were members of the committee that prepared the committee report, or have read the committee report thoroughly (perhaps performing their own research) and accept it as the group's intention can be considered "[intention] forming operative members," who have "jointly agreed to adopt the [intention]." 215 These intent-forming operative members are the members who must jointly, in the fullest sense, accept the legislation as their own intent for the group.

There may, of course, be very few operative members. Even if a member intended to the fullest extent the bill that passed the House or Senate, a conference committee might later call for changes that the member only accepts weakly for fear of killing the legislation altogether. Operative members, therefore, will most often be members of the relevant committees or subcommittees, or members of the conference committee.

In addition to fully operative members, there are "seminonoperative" members who vote for the bill, but do not play as central a role in the legislative process as a committee member might. These members can be seen as more than tacitly accepting the intentions of those who formed the bill. These members sign onto the bill and, thus, think it is the proper legislation for Congress to pass for whatever reason.

${ }^{214}$ This is drawn from TUOMELA, supra note 2, at 276.
Id. at 275 . 
Finally, there are the nonoperative members who voted against the legislation. For the legislation to be a group intention under Tuomela's formulation, these members need only tacitly accept the legislation as Congress's intent. Tacit acceptance means simply that "[a] nonoperative member ... [not] strongly overtly oppose the [intentions] accepted by the operative members, the penalty for disobeying being at least criticizability." ${ }^{216}$ Thus, while members of Congress may stridently disagree with a piece of legislation as it appears in its enacted form, it is outside the bounds of Congress's structure for a member, for example, to forcibly attempt to stop the enactment of a piece of legislation (burning every copy of the bill, destroying any computer files, etc.).

Even while disagreeing, a member of Congress is still functioning qua group member. The member must still "intentionally . . . act in a way related [to] ... the group's realm of concern such that ... she does not violate the group's central, constitutive goals, beliefs, standards, and norms." ${ }^{217}$ Part of being a member of Congress requires adopting the group's norms and authority structure and agreeing to tacitly accept any properly enacted legislation.

The operative and nonoperative members shift from bill to bill and from moment to moment throughout the bill's journey from introduction to conference committee, as Tuomela recognizes. ${ }^{218}$ There may, of course, be some members of Congress who are most frequently operative members and some who are consistently nonoperative members because of the political make-up of the current Congress. The key point is that when an individual becomes a member of Congress, she accepts the "realm of concern" and relevant authority structure of Congress. She accepts that committees will often have a great deal of control over the success and final content of bills and that a majority vote will be required for a bill to pass, regardless of which side she is on. She agrees to accept as group intent (that is, the intent of Congress) legislation that is properly enacted given the rules

216 Id. at 282

217 TUOMELA, supra note 106, at 100.

218 See TuOMELA, supra note 2, at 274 (noting that the identity of operative and nonoperative members can change between tasks). Note that those voting against the legislation might have jointly accepted a group intention that, because of the structure of Congress, the nonoperative members with respect to that intention have no obligation to accept (because it was not authorized by vote). Thus, the status of an operative member with respect to the legislation is determined once the legislation has been passed. 
and procedures of Congress, including such intricate rules as the House's special rules and the Senate's UCAs.

Thus, a member of Congress has a prima facie duty to accept these group intentions ${ }^{219}$ (at least in the weak sense) as long as she is a part of Congress; this is central to the long-term functioning of Congress $^{220}$ and consistent with the structure of Congress as given by Article I: the House and Senate set their own rules and discipline their members. ${ }^{221}$ A member of Congress has agreed to this duty, in the sense of accepting a "standing joint intention[] (polic[y]) which [is] activated in suitable circumstances but which do[es] not presuppose renewed intention-formation or renewed agreement-making." ${ }^{222}$

The minority members of Congress have agreed ahead of time to "give up their will with respect to group-binding group-[intention] formation and transfer that right to the operative members." ${ }^{223}$ Congress is, then, a type of "noncooperative joint action" where participants cooperate only in so much as they fulfill their agreement. ${ }^{224}$ Members of Congress do not necessarily help the other members more fully realize their personal goals; rather, the "agents act on their part-related preferences (utilities).,"225

Finally, there are important limitations to this account; for example, for a group intention to exist, the operative members must have been acting according to the larger structure and authorization of Congress, such that their actions oblige a nonoperative member to tacitly accept the group's intentions. Consider the case of a disagreement over the temperature in the Senate chambers. It may be the case that a special committee has been assigned the task of regulating the temperature or a vote might be taken. While the operative members in this case may have the power to change the temperature, I do not think the nonoperative members are in any way obliged to tacitly accept this as a group intention because it is not closely tied to Con-

\footnotetext{
${ }^{219}$ Note that the duty is to accept them as group intentions, not private intentions. See id. at 281 (distinguishing between group intentions accepted because of a duty arising out of group membership and any personal intentions group members may form).

${ }^{220}$ See id. (describing group members' acceptance of group intentions as essential to the integrity of the group).

${ }^{221}$ U.S. CONST. art. I, $§ 5$, cl. 2 ("Each House may determine the Rules of its Proceedings, punish its Members for disorderly Behaviour, and, with the Concurrence of two thirds, expel a Member.").

${ }^{222}$ TUOMELA, supra note 2, at 74.

${ }^{223} I d$. at 279.

${ }^{224}$ See id. at 149 (describing noncooperative joint action).

${ }^{225} I d$.
} 
gress's "realm of concern" ${ }^{226}$ and the agreements a member of Congress makes upon joining Congress. It is probably unjustified then to say that "Congress intended the temperature to be set at seventy degrees."

Thus, I conclude that Raimo Tuomela's account, as taken primarily from The Importance of $U s,{ }^{227}$ can justify understanding Congress as a collective entity with group intentions, despite the unique challenges that Congress poses to such an account. A member of Congress agrees upon entering Congress that certain members will become operative members depending on the bill in question. Once that bill is passed, even nonoperative members have an obligation to accept, at least weakly, that intention as the group's intention because of the relevant authority structure of Congress. Therefore, under Tuomela's account, Congress can properly be said to have an intention with respect to a particular piece of legislation.

\section{F. The Limits of Collective Intention for Congress}

At this point it may seem tempting to declare the problem solved and allow all evidence ${ }^{228}$ of Congress's intents, wishes, and purposes into judges' reasoning. I think, however, that such a plan would be unwarranted given the limited ways in which Congress functions as a collective entity with collective intentions. As demonstrated above, Congress can only be said to have a group or shared intention to the extent that, and on such matters as, the nonoperative members have some obligation to at least weakly accept the operative members' jointly accepted intention. What can be said about legislative purpose? ${ }^{229}$

I think that the use of "Congress's purpose" in statutory interpretation is not justified by the nature of Congress and the relationship among its members. As discussed above, the use of legislative purpose is very attractive in cases where the language of the statute supplemented by its context is still inadequate to determine a difficult case. Thus, I think and hope other, external justifications may be found for reconstructing a likely purpose of Congress or what Congress might

226 See supra note 111 and accompanying text.

227 TUOMELA, supra note 2.

${ }^{228}$ Properly authenticated, subject to whatever restrictions one might devise for the authenticity and weight of evidence of Congress's intents or purposes.

${ }^{229}$ See supra note 42 and accompanying text for my definition of legislative purpose. Note also that I mean legislative purpose that is not codified in a statute. 
have had as its purpose were it an individual or a more tightly knit organization. My argument is simply that it should be recognized that one cannot argue and reason from Congress's actual purpose because Congress is not an entity capable of forming purposes or other more elaborate states of mind. As argued above, it is not an institutional person and there are, thus, limitations on what can be ascribed to Congress.

When a member of Congress agrees to at least weakly accept what operative members decide is going to be a legislative enactment, she is giving her assent to support, at least somewhat, Congress's action in performing a performative speech act. This performative speech act is known to be a highly autonomous, textualized text, in Tiersma's sense. ${ }^{230}$ As such, the understanding is that all the intent to the highest degree possible will be contained in the text since textualization "guarantees that the text is not just authoritative, but is the complete expression of the legal actor's intent." ${ }^{231}$ No member of Congress can be said to have agreed to accept, even weakly, the other purposes, hopes or expectations that were floating around among members of Congress; thus, Congress as an entity cannot be said to have these purposes, hopes, or expectations.

Why should one adopt such a minimalist picture of congressional group structure? As demonstrated ably by Judge Becker, members of Congress cannot always be counted on to follow even their own rules. ${ }^{232}$ A much more elaborate system of norms than is empirically verifiable in Congress would be required for Congress to have "purposes." Given the evidence of only minimal norms, a theory of legislative intent succeeds because it requires only very basic commitments from each legislator. In contrast, a theory of legislative purpose requires each legislator to assent to the hopes of other legislatorssomething that the nature of Congress's behavior cannot support.

Now to return to Hibbs v. Winn. ${ }^{233}$ In Hibbs, as described in Part I.A, ${ }^{234}$ Arizona law provided a tax credit for contributions to organizations awarding scholarships to children attending private schools. ${ }^{235}$ The tax was challenged on Establishment Clause grounds, and the

230 See supra notes $184-87$ and accompanying text.

231 Tiersma, supra note 184 , at 359.

232 See Becker, supra note 181 (lamenting that although Congress has many detailed rules in place, such rules are often ignored).

233542 U.S. 88 (2004).

234 See supra notes 5-14 and accompanying text.

235 Hibbs, 542 U.S. at 92. 
state defended by arguing that the TIA barred the taxpayer's suit in federal court. The majority analyzed the "legislative purpose" behind the TIA, while the dissent responded with a textualist argument. ${ }^{236}$ Notably, however, the dissent was willing to debate Congress's purpose, stating that "the TIA's purpose is not solely to ensure that the State's fisc is not decreased."

Thus, my argument is more radical than simply siding with the dissent's views on legislative purpose; both sides of the debate refer to congressional purpose as an extant tool. While the dissent argued that legislative purpose may never trump the language of the statute, Justice Kennedy made reference to the purpose of the statute as something in existence. My conclusion would require judges to be more precise because, as I have argued, legislative purpose qua Congress's purpose is not possible given current accounts of collective intention. Because no member of Congress can be said to have a prima facie duty to accept the purposes or expectations held by the operative members of Congress when the legislation in question was enacted, inferences about the meaning of a statute based on Congress's purpose are not justified.

\section{CONCLUSION}

Despite a close to universal acknowledgment that legislative intent, however narrowly defined, must be used in statutory interpretation, doubts continually resurface about the nature of Congress as an entity capable of collective intentions. I have argued that there is a plausible account of Congress's intent drawn from work in the field of group collective intention. Such an account of collective intention must recognize the complex structure of Congress and the special nature of its activities and communicative acts. Such an account can be found in the work of Raimo Tuomela, as taken primarily from The Importance of $U s .^{238}$

Under Tuomela's account, to be a member of Congress an individual must agree that when legislation is being written, amended, and voted on certain members of Congress will become operative members. Once a bill is passed, even nonoperative members have an obligation to accept, at least weakly, that text as the group's intention;

${ }^{236}$ See id. at 94, 113 (exemplifying the opposing methods of analysis used by the majority and the dissent).

${ }^{237}$ Id. at 125 (Kennedy, J., dissenting).

238 TUOMELA, supra note 2. 
the minority members of Congress have agreed to "give up their will with respect to group-binding group-[intention] formation and transfer that right to the operative members." 239 This account is not defeated even though there are "nonoperative members who even qua members of [Congress] disagree with the ... goals of the operative members." ${ }^{240}$ Therefore, under Tuomela's account, Congress can properly be said to have an intention with respect to a particular piece of legislation.

I have further argued that while legislative purpose is a natural tool for determining the scope of statutes, analyses using "legislative purpose" must be justified by reasons extrinsic to the legislative process and any inferences that might be drawn therefrom. Because Congress's status as a complex social group and as an entity communicating via performative speech acts does not justify conclusions regarding its "purpose," such statutory analyses are mischaracterized.

As demonstrated through the analysis of Hibbs, courts may find it difficult to adopt my argument because reasoning using legislative purpose is deeply entrenched. My argument, however, is not that the content of these arguments is necessarily flawed, just that they are mislabeled. One cannot argue and reason from Congress's actual purpose because Congress is not an entity capable of forming purposes or other more elaborate states of mind. Congress's existence as a collective entity depends crucially on the hierarchy of its social organization and on the particular kinds of actions that Congress can take. In its legislative function, Congress enacts statutes; therefore, any inferences drawn from Congress's behavior or members' statements must be connected to this particular action. Members of Congress agree to group intentions only insofar as these are tied to Congress's relevant agreed-upon function: enacting legislation, a performative speech act creating autonomous texts.

${ }^{239} I d$. at 279 .

${ }^{240} I d$. at 281. 